\title{
Essays
}

\section{High Noon Revisited: Commands of Assistance by Peace Officers in the Age of the Fourth Amendment}

\author{
Jon C. Blue $\dagger^{\dagger}$
}

What duty does the citizen owe the state? The government may obviously impose an array of obligations upon the populace, ranging from paying taxes to disclosing social security numbers. ${ }^{1}$ But the question of under what circumstances the government may require us to act in a way that endangers our lives remains largely unexplored in our jurisprudence. The law concerning police commands of assistance provides an instructive context for examining this question.

Most states statutorily authorize peace officers to command bystanders to assist them in their law enforcement duties, ${ }^{2}$ and many make a failure to obey

$\dagger$ Connecticut Superior Court Judge; B.A., Carleton, 1970; J.D., Stanford, 1973. I thank Akhil Amar, Jean Blue, and Joan Gottschall for their suggestions and encouragement and Zurreen Zubairie for her painstaking review of an earlier draft.

1. See, e.g., Bowen v. Roy, 476 U.S. 693 (1986) (government may require AFDC applicants to provide Social Security numbers).

2. Statutes authorizing peace officers to command assistance but not criminalizing failures to obey such commands include IIL. ANN. STAT. ch. 38, para. 107-8 (Smith-Hurd 1980); LA. CODE CRIM. PROC. ANN. art. 219 (West 1991); MINN. STAT. ANN. § 629.30 (West Supp. 1992); MISS. CODE ANN. § 99-3-5 (1973); N.D. CENT. CODE § 29-06-03 (1991); TENN. CODE ANN. § 40-7-105 (1990); WIS. STAT. ANN. § 968.07 (West 1985). Nonpenal statutes mentioning commands of assistance but not themselves expressly authorizing such commands include IDAHO CODE $\S 19-205$ (1987); MASS. GEN. L. ch. 41, 100 (1979); MICH. COMP. LAWS ANN. $\S 123.401$ (West 1991). Cf. OHIO REV. CODE. ANN. $\S 307.47$ (Page 1987) (concerning automobiles commandeered by police officers). 
such a command a criminal offense. ${ }^{3}$ The anecdotal, ${ }^{4}$ experiential, ${ }^{5}$ and jurisprudential ${ }^{6}$ information available suggests that these laws are not widely used. Commentators ${ }^{7}$ and courts $^{8}$ have paid little attention to them. But they are by

3. Statutes making a failure to obey a command of assistance a criminal offense include ALA. CODE $\S 13 A-10-5$ (1982); ALASKA STAT. § 11.56.720 (1989); ARZ. REV. STAT. ANN. § 13-2403 (1989); ARK. CODE ANN. \$\$ 5-54-109, 12-11-104 (Michie 1987); CAL. PENAL CODE § 150 (West Supp. 1992); Colo. REV. STAT. § 18-8-107 (1990); CONN. GEN. STAT. § 53a-167b (1991); DEL. CODE ANN. tit. 11, § 1241 (Supp. 1990); FLA. STAT. ANN. § 843.06 (West 1991); HAW. REV. STAT. ANN. § 710-1011 (Michie 1988); IND. CODE ANN. § 35-44-3-7 (Bums 1985); IOWA CODE ANN. § 719.2 (West 1979); ME. REv. STAT. ANN. tit. 30-A, § 402 (West Supp. 1990); Mo. ANN. STAT. § 544.230 (Vernon 1987); MONT. CODE ANN. \& 45-7304 (1989); NEB. REV. STAT. § 28-903 (1989); NEV. REV. STAT. ANN. § 199.270 (Michie 1986); N.H. REV. STAT. ANN. § 594:6 (1986); N.M. STAT. ANN. § 30-22-2 (Michie 1978); N.Y. PENAL LAW § 195.10 (McKinney 1988); OKLA. STAT. ANN. tit. 21, § 537 (West 1983); OR. REV. STAT. $\$ 162.245$ (1991); TEX. CRM. PROC. CODE ANN. art. 2.15 (West 1977); VT. STAT. ANN. tit. 24, § 301 (1975); VA. CODE ANN. § 18.2-463 (Michie 1988); W. VA. CODE § 61-5-14 (1989).

4. My conversations with an unscientific selection of judges, law professors, attorneys, peace officers, and ordinary citizens concerning the subject of this Essay suggest that few people-including members of the legal profession-even realize that these laws exist. None of my informants had ever observed or heard of an actual command of assistance other than those involved in the published cases cited in note 6 , infra. While published cases are a notoriously inaccurate reflection of events occurring in the real world, it seems reasonably clear that commands of assistance are not given with great regularity.

5. In 13 years of practicing criminal law and three years as a state trial judge sitting periodically in misdemeanor courts, the only command of assistance case I have ever encountered is State v. Floyd, 584 A.2d 1157 (Conn. 1991), discussed in the text accompanying notes 13-15, infra.

6. The only published American cases sustaining convictions for refusing commands of assistance are Dougherty v. State, 17 So. 393 (Ala. 1895); Coleman v. State, 63 Ala. 93 (1879); Williams v. State, 490 S.W.2d 117 (Ark. 1973); State v. Santiago, 578 A.2d 668 (Conn. App. Ct. 1990), appeal dismissed, 590 A.2d 434 (Conn. 1991); State v. Deniston, 6 Blackf. 277 (Ind. 1842); State v. Ditmore, 99 S.E. 368 (N.C. 1919); State v. Shaw, 25 N.C. (3 Ired.) 20 (1842); Comfort v. Commonwealth, 5 Whart. 437 (Pa. 1840).

A conviction for this offense was reversed on statutory grounds in State v. Brown, 141 S.E.2d 311 (N.C. 1965). State v. Floyd, 584 A.2d 1157 (Conn. 1991), reversed a pretrial dismissal of a prosecution for this offense.

Cases involving commands of assistance have come before the courts in three other contexts. First, a number of persons responding affirmatively to such commands have been killed or injured, and either they or their estates have subsequently sought compensation. See Monterey County v. Rader, 248 P. 912 (Cal. 1926); Babington v. Yellow Taxi Corp., 164 N.E. 726 (N.Y. 1928); Riker v. City of New York, 126 N.Y.S.2d 229 (1953), aff d, 143 N.Y.S. 2d 620 (1955); Tomlinson v. Town of Norwood, 182 S.E. 659 (N.C. 1935); Mitchell v. Indus. Comm'n, 13 N.E.2d 736 (Ohio Ct. App. 1936); Vilas County v. Monk, 228 N.W. 591 (Wis. 1930); Village of West Salem v. Indus. Comm'n, 155 N.W. 929 (Wis. 1916). Second, persons killing or injuring those commanded have been criminally prosecuted. See Watson v. State, 3 So. 441 (Ala. 1888); Robinson v. State, 18 S.E. 1018 (Ga. 1893); State v. Bertchey, 73 A. 524 (N.J. 1909); Commonwealth v. Martin, 7 Pa. D. 219 (1898); State v. Hailey, 31 S.C.L. (2 Strob.) 73 (1847); Weatherford v. State, 21 S.W. 251 (Tex. Crim. App. 1893). Third, persons arrested by those commanded have sued the latter (with an invariable lack of success) in trespass for damages. See Reed v. Rice, 25 Ky. (2 J.J. Marsh) 44 (1829); Firestone v. Rice, 38 N.W. 885 (Mich. 1888); Moyer v. Meier, 238 P.2d 338 (Okl. 1951); Moyer v. Foster, 234 P.2d 415 (Okl. 1951); Presley v. Fort Worth \& D. C. Ry., 145 S.W. 669 (Tex. Civ. App. 1912); McMahan v. Green, 34 Vt. 69 (1861); Hooker v. Smith, 19 Vt. 151 (1847); cf. Coyles v. Hurtin, 10 Johns. 84 (N.Y. 1813) (commanded person called as witness in suit against sheriff). The vast majority of these cases are quite old, but a few are not.

7. There has been a great deal of writing, particularly in the last decade, on the Posse Comitatus Act, 18 U.S.C. $\S 1385$ (1988), which makes the willful use "of any part of the Army or the Air Force" to execute civilian laws a criminal offense. See, e.g., Walter A. Lorence, The Constitutionality of the Posse Comitatus Act, 8 U.K.C. L. REV. 164 (1939); Roger B. Hohnsbeen, Note, Fourth Amendment and Posse Comitatus Act Restrictions on Military Involvement in Civil Law Enforcement, 54 GEO. WASH. L. REV. 404 (1986); Larry C. Boschee, Note, The Posse Comitatus Act As an Exclusionary Rule: Is the Criminal To Go Free Because the Soldier Has Blundered?, 61 N.D. L. REV. 107 (1985). These works, however, have focused on issues involving the application of the Posse Comitatus Act to various military and quasi-military services. No scholarly article has dealt with the quite different constitutional problems discussed in this 
no means completely dormant, as I discovered when the case of State v. Floyd found its way to my docket. My decision in Floyd, which attempted to address the problems inherent in these statutes, was reversed by the Connecticut Supreme Court on procedural grounds. ${ }^{10}$ In doing so, that court construed Connecticut's commanding assistance statute rather narrowly in an effort to preserve its constitutionality, but serious constitutional difficulties remain even under its analysis. This Essay addresses some important problems that, for all practical purposes, remain unaddressed and unresolved. ${ }^{11}$ The facts of State v. Floyd provide a good starting point. ${ }^{12}$

On August 5, 1989, an employee of the Pratt and Whitney Aircraft Company named Michael Jamieson was involved in a motor vehicle accident in the town of Southington, Connecticut. The Southington Police Department assigned Officer Nicholas Spratto to investigate the accident. Officer Spratto determined that Jamieson had committed a motor vehicle infraction. ${ }^{13}$ Officer Spratto went to the Pratt and Whitney factory in Southington and confronted Jamieson. Jamieson became obnoxious and refused to accept a ticket.

At this point, Officer Spratto went to Gregory Floyd, a uniformed Pratt and Whitney security officer, and asked him what Pratt and Whitney's policy was for dealing with disorderly employees. Floyd said he did not know and referred Spratto to his supervisor, Kenneth Wright. Wright, also a uniformed security employee, told Officer Spratto that the policy was to call the Southington Police Department, a response which Officer Spratto of the Southington Police Department apparently found unilluminating. Officer Spratto returned to Jamieson,

Essay, triggered by commands of assistance directed at civilians.

8. The only cases to have considered the constitutionality of commanding assistance laws are State v. Floyd, 584 A.2d 1157 (Conn. 1991), and Williams v. State, 490 S.W. 2d 117 (Ark. 1973). Floyd is discussed in the text accompanying notes 13-15, infra. Williams dismissed most of the constitutional arguments presented in rather summary fashion. 1991).

9. State v. Floyd, No. CR89-66843 (Conn. Super. Ct. Jan. 25, 1990), rev'd, 584 A.2d 1157 (Conn.

10. The Supreme Court of Connecticut held that I erred in dismissing a criminal case on the basis of a statement of essential facts submitted by the prosecution pursuant to a Connecticut rule of practice rather than holding an evidentiary hearing. Floyd, 584 A.2d at 1159.

11. Although profound ethical problems are plainly raised by the factual scenarios I discuss, my analysis is a legal one. I do not address the citizen's moral duties to the state and to other citizens, for I view those duties as matters of conscience. As will be seen, I conclude that in cases involving potential danger to the summoned citizen, the decision should remain one of the citizen's conscience rather than one compelled by law.

12. In giving this summary, I commit the same sin condemned by the Supreme Court of Connecticut on appeal-relying on the prosecution's statement of essential facts. See supra note 10. I do this for three reasons. First, the essential facts are a matter of public record, having been summarized in the opinion of the Connecticut Supreme Court. See Floyd, 584 A.2d at 1159. Second, the parties gave me no reason to believe that the alleged facts are inaccurate in any significant way. Third, even if the alleged facts are, contrary to my impression, inaccurate, they nevertheless demonstrate what at least one prosecutor has recently perceived to be a legitimate basis for prosecution.

13. An infraction in Conrecticut is punishable by a maximum fine of $\$ 90$. CONN. GEN. STAT. $\$$ 51$164 m(c)$ (1991). 
who at this point became unruly. Officer Spratto decided to arrest Jamieson for breach of peace. ${ }^{14}$

Jamieson, however, resisted arrest by struggling and fighting with Officer Spratto. Unable to make the arrest singlehandedly without endangering himself, Officer Spratto commanded three civilians to assist him: Floyd and Wright, the uniformed security officers he had previously consulted, and John Paradis, a maintenance supervisor wearing a jacket and tie. All three refused to help Officer Spratto. Paradis stated that he could not do so. Eventually another police officer arrived, and the officers took Jamieson into custody. The state subsequently charged Floyd, Wright, and Paradis with the crime of failure to assist a peace officer. ${ }^{15}$

State v. Floyd presents a variation on the theme of the well-known motion picture, High Noon. ${ }^{16}$ In High Noon, the marshal of a small western town, memorably played by Gary Cooper, attempts to raise a posse of special deputies to subdue an outlaw scheduled to arrive on the noon train. None of the townspeople will help him. Some people are simply apathetic, but most are afraid or concerned for their wives and children. The marshal must eventually do the job himself. It does not seem to have occurred to him that he could simply arrest the citizens who refused to assist him. ${ }^{17}$

We instinctively admire heroism, and the reluctance of citizens to put themselves at risk to help an embattled peace officer hardly seems admirable. It is, however, an understandable characteristic and one that is not unequivocally blameworthy. There have been, to be sure, instances of failure to assist others that merit the strongest possible moral condemnation. The most celebrated

14. Id. $\$ 53 \mathrm{a}-181$. Breach of peace is a misdemeanor in Connecticut, punishable by up to six months in prison. Id. $\S 53 \mathrm{a}-36$.

15. Id. $\S 53 \mathrm{a}-167 \mathrm{~b}$. This statute provides that "[a] person is guilty of failure to assist a peace officer or fireman when, commanded by a peace officer or fireman authorized to command assistance, he refuses to assist such officer or fireman in the execution of his duties." A violation of this statute is a misdemeanor punishable by imprisonment for up to one year. $I d$. $\$ 53 \mathrm{a}-36$. Section $53 \mathrm{a}-167 \mathrm{~b}$ on its face applies only to officers "authorized to command assistance" and does not itself grant such authorization. Section 7-276, however, provides that members of municipal police departments "shall have all such authority with respect to the service of criminal process and the enforcement of the criminal laws as is vested by the general statutes in police officers and constables." Id. § 7-276. Section 7-90, in turn, specifically provides that, "[a]ny constable, when necessary, may command any person to assist him in the execution of the duties of his office." Id. § 7-90.

16. HIGH NOON (United Artists 1952). High Noon is perhaps better understood as an allegory of the reluctance of the American people to come to the assistance of their friends during the McCarthy era than as a description of exemplary law enforcement techniques. The screenwriter, Carl Foreman, was blacklisted after writing the film for refusing to cooperate with the House Committee on Unamerican Activities. Amanda Foreman, High Noon at the P.C. Corral, N.Y. TMES, Mar. 20, 1991, at A29. High Noon's portrayal of a peace officer's conduct has had at least one notable cinematic detractor. Howard Hawks was so infuriated at what he perceived to be Gary Cooper's groveling behavior in High Noon that he made Rio Bravo "to show that a professional lawman ... wouldn't ask common folk for help against the gunmen." DANNY PEARY, GUIDE FOR THE FILM FANATIC 194 (1986); RIO BRAVO (Wamer Bros. 1958). The sheriff in Rio Bravo, portrayed by John Wayne, dismissed the idea of commanding a citizen posse to resist the outlaws threatening him, stating that, "What I'd have is some well-meaning amateurs, most of them worried about their wives and kids."

17. It should be noted that the marshal in High Noon requested assistance rather than commanded it. 
instance that comes to mind is that of the thirty-seven New York City residents who looked on from the safety of their apartments while Catherine Genovese was murdered in 1964 and who did not even call the police. ${ }^{18}$ But the fictitious townspeople who refused to assist the marshal in High Noon and the real people who refused to assist Officer Spratto in State v. Floyd occupy a very different place on the moral spectrum. For them, the requested acts of assistance were not risk-free.

The outlaw in High Noon was a murderer accompanied by three friends, all of whom carried guns and were willing to use them. Jamieson, the struggling man in Floyd, was apparently unarmed, but there was no way safe way to determine this fact in advance. Anyone who spends a single day in an arraignment court in any present-day urban area will leave with the distinct impression that the number of armed and dangerous people in our society is appallingly high. Many people with whom I have discussed the Floyd scenario have categorically stated that they would have refused a command to subdue Jamieson for just this reason. There are, in any event, a number of documented cases in which persons who have obeyed commands of assistance have been killed or injured in the process. ${ }^{19}$ It is not entirely blameworthy for a fortuitously summoned citizen - and particularly one with a dependent spouse or children - to decline to risk being added to the list.

This leads to a moral anomaly in the law. The neighbors who ignored Catherine Genovese's screams and did not bother to call the police committed no crime in doing so. They did not even breach any legal duty known to the law of torts. The same is true of the hypothetical person known to law students everywhere who declines to toss a lifesaver to a drowning man (assuming that he did not place the man in danger in the first place). But the comparatively less blameworthy person who refuses to assist a police officer in his dangerous work is punished as a criminal. While the duty to assist a peace officer is arguably an attribute of membership in an organized society, the justification for this duty requires careful scrutiny.

$$
* * * *
$$

The antecedents of existing commanding assistance statutes are centuries old. Their origins lie not in the urban landscape of present-day America but in the forests and walled cities of medieval England. Long before the creation of

18. See Martin Gansberg, 37 Who Saw Murder Didn't Call the Police: Apathy at Stabbing of Queens Woman Shocks Inspector, N.Y. TMES, Mar. 27, 1964, at 1. A 38th witness called the police after Ms. Genovese was dead. Id. A thoughtful discussion of this famous case can be found in LEO KATZ, BAD ACTS AND GUIITY MINDS 135-37 (1987).

19. See supra note 6 . 
organized police forces, ${ }^{20}$ the common law process of apprehending suspected felons was the hue and cry. ${ }^{21}$ The person discovering a felony would raise a cry of "Out! Out!" Prompting the neighbors to turn out with their bows, arrows, and knives. The "hue" would be passed by horn-blowing from town to town until the ad hoc posse caught the malefactor or gave up the chase. Any malefactor overtaken would receive summary justice. A court would hurriedly assemble for the purpose and, without allowing the defendant to say anything in his defense, the crowd would promptly hang the defendant, behead him, or hurl him from a cliff..$^{22}$ The victim of the crime would sometimes have the honor of acting as amateur executioner. ${ }^{23}$

This was, as Pollock and Maitland aptly put it, "barbaric justice,"24 stripped of any semblance of what would now be considered due process and hearkening back to ancient times in its swiftness and brutality. But the hue and cry was not out of place in feudal society. Obligations to participate in the peace-keeping functions of that society were widespread. In the absence of a professional army, the duty of military service was rooted in the tenure of land. ${ }^{25}$ Similarly, the absence of a professional constabulary meant that all citizens were expected to pursue and capture outlaws, killing them if necessary. ${ }^{26}$ More generally, perceived notions of communitarianism were very strong. ${ }^{27}$ In fact, if a malefactor was not caught by the hue and cry, a financial

20. The hue and cry is mentioned in THE TREATISE ON THE LAWS AND CUSTOMS OF THE REALM OF ENGLAND COMMONLY CALLED GLANVILL 175 (G.D.G. Hall ed., 1983), and 2 HENRY BRACTON, ON THE LAWS AND CUSTOMS OF ENGLAND 350 (Samuel E. Thome trans., 1968).

21. "Hue" derives from the French huer, meaning "to shout."

22. The form of punishment varied with the locality. "In some sea-port towns the criminal was tied to a stake below high-water mark and left to drown. At Winchester, he was mutilated .... Burying alive seems to have been practiced at Sandwich, Lyon, Dover." 2 FREDERICK POLLOCK \& FREDERIC W. MATILAND, THE HISTORY OF ENGLISH LAW 496 n.7 (2d ed. 1905).

23. Id. at 578-79.

24. $1 d$. at 579.

25. 1 id. at 252 .

26. $I d$. at 476-77.

27. One way to think of the role of the individual in medieval society is in terms of the sculptures in a medieval cathedral. In these sculptures, the human body is typically conventionalized into a column, giving the statues the appearance "of forming part of the building and of sustaining it." The individual is an organic part of the architecture as a whole. MARGARET MARRIAGE \& ERNEST MARRIAGE, THE SculPTURES OF CHARTRES CATHEDRAL 22 (1909). The idea of communitarianism has enjoyed a scholarly resurgence in recent years, and the communitarian-liberal debate among legal theorists has resulted in a prodigious amount of scholarship. Compare, e.g., Paul W. Kahn, Community in Contemporary Constitutional Theory, 99 YALE L.J. 1 (1989), and authorities discussed therein with Robin West, The Supreme Court, 1989 Term-Foreword: Taking Freedom Seriously, 104 HARV. L. REV. 43 (1990). Much of this debate concems problems of political deliberation, the equality of political actors, and participation in governmental processes that are well beyond the scope of this Essay. See generally Cass R. Sunstein, Beyond the Republican Revival, 97 YALE L.J. 1539, 1541-42 (1988). Of course, my approach to the Fourth Amendment might fairly be termed a liberal one in that $I$ view that amendment as giving the individual a certain autonomy from the state and, in terms of the ethical problems raised by the factual scenarios I discuss, an ability to define his own values. See supra note 11. But the existence of this contemporary debate should not obscure the fact that the communitarian notions of the Middle Ages originated in a "feudal world of sect, family and guild," Kahn, supra, at 63, vastly different from the world of individual rights secured by the written constitution of the nation state that we now inhabit. 
penalty would be levied on the entire township. ${ }^{28}$

In 1275, the first Parliament of Edward I, perceiving that participation in the hue and cry was declining, obliged citizens to join in the process by force of positive law, and gave sheriffs the power to command such pursuits. ${ }^{29}$ The First Statute of Westminster provided: "That all generally be ready and apparelled, at the Commandment and Summons of Sheriffs, and at the Cry of the Country, to sue and arrest felons, when any need is ... and they that will not do so . . . shall make a grievous fine to the King. ${ }^{.30}$ Ten years later, the Statute of Winchester not only affirmed the obligation of the populace to join in the hue and cry, but also commanded every man between fifteen and sixty years of age to have in his house a quantity of arms "to keep the Peace." Wealthy subjects were required to keep "an Hauberke, a Breast-plate of Iron, a Sword, a Knife, and an Horse." The less wealthy were obliged to keep swords, knives, bows, and arrows. ${ }^{31}$

The Statutes of Westminster and Winchester were, in Bishop Stubbs' words, "monument[s] of the persistence of primitive institutions working their way through the superstratum of feudalism and gaining strength in the process. ${ }^{, 32}$ Those monuments would not only stand in England for centuries, ${ }^{33}$ but they cast their lengthy shadows across the Atlantic as well. In $1641,{ }^{34}$ the Colony of Massachusetts ordered that "all Hue \& cries shall be duly received and diligently pursued to full effect." ${ }^{35}$ That simple statute was followed in 1646 by a considerably more colorful enactment:

[E]verie Constable within our Jurisdiction shall henceforth have full power to make, signe \& put forth Pursutes or Hue-\&-cries after Mur-

28. 2 BRACTON, supra note 20 , at 350 .

29. First Statute of Westminster, 1275, 3 Edw., ch. 9.

30. Id.

31. Statute of Winchester, 1285, $13 \mathrm{Edw} . \mathrm{I}, \mathrm{ch} .6$. There is evidence that this statute was intended in large part to keep the peace while Edward went abroad to Gascony. MAURICE POWICKE, THE THIRTEENTH CENTURY 357 (1962).

32. William StubBS, Select Charters 288, 293 (1870).

33. The arms provisions of the Statute of Winchester were repealed in the 17th century, but English sheriffs retained their statutory power to command the citizenry to arrest felons until 1967. In 1939, the Privy Council wamed the sheriffs that they might have to command the civilian population to assist them in defending their counties should an invasion occur. 42 HALSBURY's LAWS OF ENGLAND 558 (4th ed. 1983). English constables are still thought to have the power to call upon bystanders to assist them in cases of reasonable necessity, 11(1) HALSBURY'S LAWS OF ENGLAND 255 (4th ed. reissue 1990), although no English court has been called on to enforce this power since the mid-19th century. See Queen v. Sherlock, 1 L.R.-Cr. Cas. Res. (1866); Regina v. Brown, 174 Eng. Rep. 522 (1841).

34. At the time of this New World legislation, the most distinguished legal commentators in England unquestioningly accepted the medieval law of the hue and cry. Edward Coke, who died in 1634, summoned a characteristically impressive array of medieval precedent of the hue and cry in his Second Institutes. 2 EDWARD COKE, INSTITUTES OF THE LAWS OF ENGLAND *171-73. Matthew Hale, a young lawyer at the time, later invoked Bracton and the Statutes of Westminster and Winchester as decisive on the issue. 2 MaTtheW Hale, THE HistoRy OF THE PLEAS OF THE CROWN *98-99. Over a century later, William Blackstone, relied similarly on this medieval legislation, 4 WILLIAM BLACKSTONE, COMMENTARIES *290.

35. THE BOOK OF THE GENERAL LAUUES AND LIBERTYES CONCERNING THE INHABITANTS OF THE MASSACHUSETTS 13 (photo. reprint 1929) (1648). 
therers, Manslayers, Peace-breakers, Theevs, Robbers, Burglarers and other Capital offenders, where no Magistrate is neer hand .... And if it appear by good testimonie, that any shal wilfully, obstinately or contemptuously refuse or neglect to assist any Constable ... he shall pay to the use of the Country fourty shillings. And that no man may plead ignorance for such neglect or refusal, it is ordered that everie Constable shall have a black staffe of five foot long, tipped at the upper end, about five inches with brasse, as a badge of his office, which he shal take with him when he goeth to discharge any part of his office. ${ }^{36}$

The Colony of Connecticut passed similar legislation (omitting the black staff requirement) in $1650 .{ }^{37}$ As noted at the beginning of this Essay, ${ }^{38}$ most states now require similar duties of their citizens as expressed in somewhat more modern statutory language.

This is an impressive lineage entitled to considerable respect, even if one is not Justice Scalia. ${ }^{39}$ In the words of Justice Holmes, "If a thing has been practiced for two hundred years by common consent, it will need a strong case for the Fourteenth Amendment to affect it." ${ }^{40}$ However, while the antiquity of a practice plainly creates a presumption of the practice's continued validity, ${ }^{41}$ it is not necessarily conclusive in constitutional adjudication. That much, at least, continues to be acknowledged by a clear majority of a Supreme Court

36. Id.

37. 1 THE PUBLIC RECORDS OF THE COLONY OF CONNECTICUT 522 (1850).

38. See supra notes 2-3 and accompanying text.

39. $C f$., Pacific Mut. Life Ins. Co. v. Haslip, 111 S. Ct. 1032, 1047-54 (1991) (Scalia, J., concurring) (arguing that traditional practice of allowing juries to determine punitive damages does not violate due process); Burnham v. Superior Court, 110 S. Ct. 2105, 2109-17 (1990) (plurality opinion of Scalia, J.) (reviewing historical support for notion that service of process confers state court jurisdiction over physically present nonresidents); Michael H. v. Gerald D., 491 U.S. 110, 122-27 (1989) (plurality opinion of Scalia, J.) (tracing law's history of respect for marital family as far back as Bracton).

40. Jackman v. Rosenbaum Co., 260 U.S. 22, 31 (1922). It is, however, far from clear that the power to command assistance has been practiced by anything approaching common consent during the past 200 years. See supra notes 1-6 and accompanying text.

41. See Haslip, 111 S. Ct. at 1043 (majority opinion); id. at 1065 (O'Connor, J., dissenting). The existence of this presumption is clear, but its exact rationale has never been fully articulated. Original intent is one of its bases, for if a particular practice was widespread in 1791 or 1868 when the Bill of Rights and the 14th Amendment were respectively ratified, the Framers of those amendments likely understood that practice to be prevailing and did not intend to overturn it. See, e.g., id. at 1043; Michael H., 491 U.S. at 127 n.6 (Scalia, J.); Bowers v. Hardwick, 478 U.S. 186, 192-93 (1986). But the Supreme Court has periodically looked to "history" and "tradition" in a way that does not exclusively, or even primarily, focus on the Framers' intent. See, e.g., Griswold v. Connecticut, 381 U.S. 479, 501 (1965) (Harlan, J., concurring) (invoking "respect for the teachings of history"); Snyder v. Massachusetts, 291 U.S. 97, 105 (1934) (invoking "principle[s] of justice so rooted in the traditions and conscience of our people as to be ranked as fundamental"). Perhaps the best that can be said is that the longer a practice has endured, the more "historical" or "traditional" it has become, and the more reluctant a court will be to overturn it. Much, however, depends on the particular constitutional provision in question. In due process cases, the presumption of validity accorded a practice with deep historical roots will be high. An analysis of an express guarantee of the Bill of Rights, however, must ultimately tum on the language and meaning of that guarantee, even if the language and meaning are counterhistorical. See Haslip, $111 \mathrm{~S}$. Ct. at 1052 (opinion of Scalia, J.). 
not otherwise known for its aversion to antiquity. ${ }^{42}$ As the Court said in somewhat more venturesome days, there is a "need to be open to reassessment of ancient practices other than those explicitly mandated by the Constitution." ${ }^{43}$ Justice Holmes also wrote:

It is revolting to have no better reason for a rule of law than that so it was laid down in the time of Henry IV. It is still more revolting if the grounds upon which it was laid down have vanished long since, and the rule simply persists from blind imitation of the past. ${ }^{44}$

The history of commanding assistance laws suggests that the grounds upon which those laws were laid down have indeed long since vanished. Consequently, a reassessment of the ancient practice of summoning the populace to apprehend criminals is in order.

$$
* * * *
$$

The society of thirteenth-century England that produced the Statutes of Westminster and Winchester differed in many ways from seventeenth-century Massachusetts and Connecticut, which enacted the statutory antecedents of modern American commanding assistance legislation. Yet, although centuries apart, these societies did share two important characteristics. Neither had any sort of organized police force or tradition of individual constitutional rights. Profound changes have since occurred with respect to each of these characteristics.

Organized police forces are a product of the nineteenth century. ${ }^{45}$ Prior to that time, the relatively few constables, sheriffs, and watchmen in existence could not be expected to keep the peace by themselves. ${ }^{46}$ If the peace was to be kept at all, it was because armed citizens were ready to respond to the hue

42. See Haslip, 111 S. Ct. at 1043 (majority opinion); id. at 1065 (O'Connor, J., dissenting).

43. Williams v. Illinois, 399 U.S. 235,240 (1970). Williams was favorably cited by the majority in

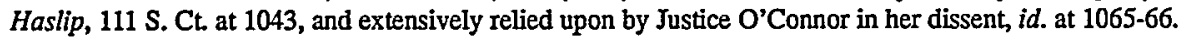

44. Oliver W. Holmes, The Path of the Law, 10 HARV. L. REV, 457, 469 (1897).

45. The first organized police force of the sort that we would now recognize was established in London by An Act for improving the Police in and near the Metropolis, $1829,10 \mathrm{Geo} .4$, ch. 44 . The act was the brainchild of the Home Secretary, Sir Robert Peel, and British policemen are to this day known as bobbies.

46. The peace officers of the time were not merely few in number. "[E]ighteenth Century constables were so poorly paid that only old men could afford to take the job." Comment, An Historical Argument for the Right to Counsel During Police Interrogation, 73 YALE L.J. 1000, 1035 n.200 (1964). Deputy constables, in many instances, were "characters of the worst and lowest description; having no salary, but living by extortion, and countenancing all species of vice." John Timbs, Curiosities of London 682 (2d ed. 1867). The preface to An Act for improving the Police in and near the Metropolis, 1829, 10 Geo. 4, ch. 44, states that the previously existing Nightly Watch and Nightly Police were inadequate, among other reasons, "by reason of the frequent Unfitness of the Individuals employed [and] the Insufficiency of their Number." Id.; see also WILlIAM SHAKeSPEARE, MUCH ADo ABOUT NOTHING act 4, sc. 2, at 80 (Yale University Press 1917) (1600) (remarks of Constable Dogberry). 
and cry. ${ }^{47}$ This is no longer the case. Our society now has large, organized, well-equipped and well-trained federal, state, and local police forces to keep the peace. At the same time, law-abiding citizens are no longer expected to be armed, much less trained in the use of arms. Indeed, most states now make it a crime to carry a concealed weapon, and some criminalize the carrying of unconcealed weapons without a permit. ${ }^{48}$ If modern peace officers had to rely upon the ancient power of raising the county, they would no longer have the sword-wielding, hauberke-clad citizens of medieval England at their beck and call. The persons much more likely to be bearing arms would be the persons being pursued. ${ }^{49}$

The establishment of organized police forces and the statutory disarmament of the populace are not the only significant developments that have occurred since the enactment of the colonial antecedents to modern commanding assistance laws. The United States now has a two-centuries-old written constitution that contains explicit guarantees of individual rights. The Fourth Amendment and the requirements of due process restrict the power of the state in ways that call for a reconsideration of the duties and the risks that the state has historically been able to impose on its citizenry.

$$
* * * *
$$

The Fourth Amendment provides: "The right of the people to be secure in their persons . . . against unreasonable . . . seizures, shall not be violated."50 Although we ordinarily think of the Fourth Amendment in terms of police activities directed at persons suspected of crime, its text is not so limited. The

47. The 17th-century concept of the militia provides a significant parallel to this state of affairs. Public sentiment at the time of the Constitution's adoption "strongly disfavored standing armies; the common view was that adequate defense of country and laws could be secured through the Militia-civilians primarily, soldiers on occasion." United States v. Miller, 307 U.S. 174, 179 (1938). This view is reflected in the preamble to the Second Amendment. U.S. CONST. amend. II ("[a] well regulated Militia, being necessary to the security of a free State"). Professor Levinson has noted that "[t]here is strong evidence that "militia" refers to all of the people, or at least all of those treated as full citizens of the community." Sanford Levinson, The Embarrassing Second Amendment, 99 YALE L.J. 637, 646-47 (1989). In contrast, an "army" was feared, as Professor Amar has recently observed, because "[i]t was not composed of a randomly conscripted cross-section . . . but was instead filled with hired guns." Akhil R. Amar, The Bill of Rights as a Constitution, 100 YALE L.J. 1131, 1169 (1991); see also Henry W. Longfellow, Paul Revere's Ride, in THE COMPLETE POETICAL WORKS OF LONGFELLOW 207 (1940). In modern times, of course, we have the very sort of standing army that the founding fathers opposed, and no true citizen militia has been summoned in many years.

48. See, e.g., CONN. GEN. STAT. § 53-206 (1991) (making it criminal, punishable by three years in prison, to carry any "dangerous or deadly weapon or instrument" without written permit). It is well known to anyone who watches current television news broadcasts that many police organizations are prominent supporters of proposed federal and state legislation further restricting handgun ownership.

49. In addition, the weapons wielded by the persons being pursued are much more powerful than they once were. See Tennessee v. Garner, 471 U.S. 1, 14-15 (1985). It is not uncommon for an urban criminal to have at his disposal firepower that would make a police department envious.

50. U.S. CONST. amend. IV. Most state constitutions contain analogous provisions. See, e.g., CoNN. CONST. art. I, § 7. ("The people shall be secure in their persons . . . from unreasonable . . . seizures . . . ."). 
text is explicitly concerned with the security of the person..$^{51}$ It has been clear since Terry $v$. Ohio ${ }^{52}$ - and this much, at least, remains unaltered by California v. Hodari $D .{ }^{53}$ - that "the Fourth Amendment governs 'seizures' of the person that do not eventuate in a trip to the station house and prosecution for crime." 54 The " "seizures' of the person" that the Fourth Amendment governs are those defined by the common law of arrest. ${ }^{55}$ This concept includes not only physical restraints, but submissions to the assertion of authority. ${ }^{56}$ The Supreme Court stated in Terry that when an officer by a show of authority "has in some way restrained the liberty of a citizen . . . a 'seizure' has occurred." Hodari $D$. adds that the restraint must be a successful one: that is, either the citizen whom the officer is seeking to restrain must submit to the restraint or the officer must use physical force. ${ }^{58}$ Neither the Fourth Amendment's text nor the line of cases from Terry to Hodari D. limits the prohibition on restraints to those imposed on persons suspected of a crime. ${ }^{59}$ Rather, as the text of the amendment emphatically informs us, freedom from unreasonable restraints affecting the security of the person ${ }^{60}$ is " $[t]$ he right of the people."

The implications of this doctrine for commands of assistance are reasonably clear. If submission to an assertion of authority constitutes a seizure, so does a command of assistance to which the commanded person submits. ${ }^{62}$ The

51. The Supreme Court has voiced concern-expressed in terms more philosophical than textual-when it has considered cases involving actual invasions of the physical person. See Winston v. Lee, 470 U.S. 753 (1985) (surgery); Schmerber v. California, 384 U.S. 757 (1966) (blood test).

52. 392 U.S. 1 (1968)

53. 111 S. Ct. 1547 (1991). Hodari D.'s favorable discussion of Brower v. Inyo County, 489 U.S. 593 (1989), makes it clear that the Fourth Amendment concept of "seizure" extends to successful (if that is the word for roadblocks that cause fatal accidents) demonstrations of authority that could not be described as arrests in the colloquial (as distinct from the legal) sense of the word. See Hodari D., $111 \mathrm{~S}$. Ct. at 1552. Both opinions were written by Justice Scalia.

54. Terry, 392 U.S. at 16.

55. Hodari $D ., 111 \mathrm{~S}$. Ct. at 1551 n.3.

56. Id. at 1551 .

57. 392 U.S. at 19 n.16.

58. Hodari D., $111 \mathrm{~S}$. Ct. at 1551 . This qualification, while clear enough from Hodari $D$., is a troubling one for purposes of my analysis. The application of the Fourth Amendment "seizure" provision requires some physical restraint, yet only persons who submit to commands of assistance have suffered such restraint. In this way, persons not submitting to such commands risk criminal prosecution without a Fourth Amendment defense. See supra note 3. This is not an equitable state of affairs, but it in no way alters the fact that successful commands of assistance affecting the security of the person are Fourth Amendment "seizures."

59. If anything, of course, persons not suspected of crime should be more free, rather than less free, from official restraint. Although the Supreme Court has occasionally suggested that the principal concern of the Fourth Amendment is with "criminal investigations," Ingraham v. Wright, 430 U.S. 651,673 n.42 (1977); Whalen v. Roe, 429 U.S. 589, 604 n.32 (1977), those suggestions came in cases having nothing to do with the police. Police-imposed restraints that threaten personal security are another matter altogether.

60. Not all restraints affect the security of the person. Subpoenas that command an individual to appear and give some types of evidence in court are unquestionably restraints on liberty but are not Fourth Amendment "seizures." See United States v. Dionisio, 410 U.S. 1, 14-15 (1972) (compelled voice exemplars involved no intrusion on dignity and privacy). Restraints that affect the security of the person are entirely different.

61. U.S. CoNST. amend. IV.

62. Hodari $D$. necessarily implies that a command of assistance to which the commanded person does not submit is not a "seizure." Of course, in that event, the commanded person will, in most jurisdictions, 
commanded person is certainly not free to leave. ${ }^{63}$ If he refuses to obey the command, he will, at least in most jurisdictions, find himself in the dock. If he obeys it, and the command is anything like the one given Floyd, Wright, and Paradis, the security of his person may be in considerable jeopardy.

This is not simply a matter of the bumps and bruises that might ordinarily be expected to accompany the apprehension of a struggling criminal. The real danger is that the person to be apprehended may be armed and that there is often no way to ascertain this fact in advance. As noted above, ${ }^{64}$ there are a number of known instances in which persons obeying commands of assistance have been killed or seriously injured. The frightening array of weaponry now available on urban streets and the impulsiveness with which that weaponry is often used only increase this danger. Under these circumstances, an attempt by an unarmed civilian to apprehend a suspected criminal is a form of Russian roulette.

A person against whom the police have used deadly force has been "seized" within the meaning of the Fourth Amendment. ${ }^{65} \mathrm{~A}$ person commanded by the police to risk death or injury should not receive different Fourth Amendment treatment.

$$
* * * *
$$

Commands of assistance raise profound questions of substantive due process as well, for as the Supreme Court recognized in Cruzan v. Director, ${ }^{66}$ seizures of the body have long been thought to "implicate substantial liberty interests. ${ }^{" 67}$ Justice O'Connor succinctly stated in her Cruzan concurrence that "our notions of liberty are inextricably entwined with our idea of physical freedom and self-determination."

The equation of liberty with personal security is as old as the Magna Charta and its declaration that "[n]o freeman shall be taken or imprisoned . . . but by lawful judgment of his peers, or by the law of the land." believe that this equation underlies, at least to some extent, the right to "life, liberty and the pursuit of happiness" recognized in the Declaration of Independence. Thomas Jefferson, author of the Declaration, was well acquainted with

have committed a crime. See supra notes 3,58 .

63. Prior to Hodari $D$. this was the definition-or at least the apparent definition-of a Fourth Amendment "seizure." See INS v. Delgado, 466 U.S. 210, 215 (1984). Hodari D. holds that this test "states a necessary, but not a sufficient condition for seizure." $111 \mathrm{~S}$. Ct. at 1151.

64. See supra note 6.

65. Tennessee v. Gamer, 471 U.S. 1,7 (1985).

66. 110 S. Ct. 2841 (1990).

67. Id. at 2851.

68. Id. at 2856 (O'Connor, J., concurring).

69. 10 HALSBURY'S STATUTES OF ENGLAND AND WALES 15-16 (4th ed. 1985) (emphasis added); see also Ingraham v. Wright, 430 U.S. 651, 673 n.41 (1977); Charles E. Shattuck, The True Meaning of the Term "Liberty" in those Clauses in the Federal and State Constitutions Which Protect "Life, Liberty, and Property," 4 HARV. L. REV. 365, $372-73$ (1891). 
the work of Francis Hutcheson, an influential Scottish philosopher of the time. ${ }^{70}$ Hutcheson viewed the right to life as involving not "being exposed to death, or wounds"" and the right to what he called "natural liberty" as requiring that one's actions not "be under the direction of others."

Cruzan echoes these concerns by invoking the common law $^{73}$ and due process $^{74}$ notions of bodily integrity. The Court found the high standard of proof that Missouri required before allowing Nancy Cruzan to die justified by her "deeply personal" interest in "[t]he choice between life and death." All of the above makes clear that state actions directly threatening the security of the person are subject to the demands of due process.

Of course, a determination that a person has been "seized" for purposes of the Fourth Amendment or has a "liberty" interest for purposes of due process does not end the inquiry. In each context, established doctrine requires that the constitutional status of the relevant practice-i.e., whether the seizure is unreasonable for Fourth Amendment purposes or whether the practice violates the demands of substantive due process - be ascertained by a balancing of competing interests. ${ }^{76}$ In the context of commands of assistance, the competing interests are the liberty and Fourth Amendment interests of the person commanded, on the one hand, and the governmental interests that assertedly justify the command, on the other. ${ }^{77}$

A balancing process of this description inescapably involves judgment calls. Distinctions can, however, be made. Because the Fourth Amendment and the historical understanding of liberty focus particularly on the security and integrity of the person, we can distinguish between commands of assistance that involve danger to the person commanded and those that do not. An officer's command to a bystander to telephone 911 is unlikely to expose that bystander to any danger. On the other hand, an officer's command to a bystander to subdue a struggling criminal or to take someone into custody presents a very real possibility of danger.

Recall that it was the presence or absence of danger that created the moral distinction between the persons who heard Catherine Genovese scream and did not call the police, and the persons who refused to assist the marshal in High

70. A number of Hutcheson's works were in the library Jefferson sold to Congress. Following that sale, Jefferson repurchased two of Hutcheson's works for his personal library. GARRY WILL, INVENTING AMIERICA 201 (1978).

71. FRANCIS HUTCHESON, A SYSTEM OF MORAL PHLOSOPHY 293 (1755).

72. Id. at 294. Blackstone, at about the same time, opined that "the residuum of natural liberty, which is not required by the laws of society to be sacrificed to public convenience" includes both the right of "personal security" and the right of "personal liberty." 1 BLACKSTONE, supra note 34 , at *129.

73. Cruzan v. Director, 110 S. Ct. 2841, 2846 (1990).

74. Id. at 2851 .

75. Id. at 2852 .

76. Id. at 2851-52 and authorities cited therein (due process); Tennessee v. Gamer, 471 U.S. 1, 8 (1985) (Fourth Amendment).

77. Cf. United States v. Place, 462 U.S. 696, 703 (1983) (Fourth Amendment); Youngberg v. Romeo, 457 U.S. 307,320 (1982) (due process). 
Noon or Officer Spratto in the Floyd case. ${ }^{78}$ The presence or absence of danger is important for Fourth Amendment and due process purposes as well. When a command of assistance presents a significant possibility of danger to the person commanded-and the contemporary prevalence of concealed weapons transforms any command to take another person into custody into such a command-the government must have a weighty interest to justify that command. The modern development of organized police forces has diminished this interest considerably. At the same time, the danger to the unarmed, untrained citizen in assuming law enforcement work has become more substantial. Such commands are therefore no longer consistent with the requirements of the Constitution.

$$
* * * *
$$

It should not be inferred from this analysis that the government may never require the citizen to submit himself to danger. All citizens of this country, in the language of the Selective Draft Law Cases, ${ }^{79}$ have the "supreme and noble duty of contributing to the defense of the rights and honor of the nation."

Military service, however, is a special case. Congress has express constitutional authority to raise and support armies. ${ }^{81}$ This power is vital to our nation's existence, which is a prerequisite for the existence of our constitutional liberties. ${ }^{82}$ Citizen posses lack such a compelling justification. They are neither authorized by any express constitutional provision, nor, given the rise of organized police forces, needed to keep the peace. Moreover, the Military Selective Service $\mathrm{Act}^{83}$ has historically employed a highly regulated procedure, carefully delineating the persons liable for training and service, the manner of their selection, and the appropriate deferments and exemptions. ${ }^{84}$ Commands of assistance are subject to none of these refinements but instead rely on the summary, ad hoc, and unreviewable decisions of police officers on the beat. A person drafted for military service can go to an administrative board and show good cause, at least within statutory limits, as to why he should not be inducted. His counterpart summoned by a peace officer has no such recourse.

78. See supra notes $12-19$ and accompanying text.

79. 245 U.S. 366 (1918).

80. Id. at 390 .

81. U.S. CONST. art. I, § 8.

82. For a powerful discussion of this requirement, see Abraham Lincoln, Opinion on the Draft, reprinted in ABRAHAM LINCOLN, SPEECHES AND WRTINGS, 1859-1865, at 504-09 (Don E. Fehrenbacher ed., 1989).

83. 50 U.S.C. app. $\$ \S 451-473$ (1988).

84. This is not to say that the draft law has been in any way a model of faimess, for inequities like the exclusion of women and the student deferment in the Vietnam War (not to mention the outright purchase of deferments in the Civil War) have existed throughout its history. These inequities, however, have at least had the virtue of being publicly acknowledged products of deliberate congressional choice. The existence of considered exemptions and procedures gives the system some minimal evenhandedness of application. 
Given these facts, the more accurate analogy to the command of assistance is not the military draft but the notorious British practice of impressment, an institution which the Founding Fathers abhorred. ${ }^{85}$ That ordinary citizens should be subject to summary impressment into hazardous police duty is inconsistent with our basic notions of constitutional liberty.

The Supreme Court of Connecticut took a somewhat different view of these issues in the Floyd case. ${ }^{86}$ Recognizing the serious constitutional issues raised by the case, the court chose to address them by construing Connecticut's commanding assistance statute ${ }^{87}$ as authorizing such commands "only when such assistance is both demonstrably necessary and reasonable under all the circumstances. ${ }^{188}$ This approach has the virtue of appearing to be reasonable, but it is in fact a troubling means of dealing with a practice that by its nature requires split-second decisions involving the safety of the person, where the person commanded will have no ready means of identifying a deficient command. ${ }^{89}$ Judges, prosecutors, and peace officers have for years voiced the concern that Fourth Amendment law is too confusing to be understood by policemen on the beat. ${ }^{90} \mathrm{~A}$ generalized rule of reasonableness reduces the law to a morass where no one, policeman or citizen, can determine his rights and responsibilities in advance. Moreover, as Professor Amsterdam has observed:

If there are no fairly clear rules telling the policeman what he may and may not do, courts are seldom going to say that what he did was unreasonable. The ultimate conclusion is that "the people would be 'secure in their persons, houses, papers, and effects,' only in the discretion of the police."91

It would be far better to have some hard and fast rules that citizens of this country could intelligently follow. Given the realities of modern life, it behooves us to decree that commands of assistance that subject the person commanded to the possibility of personal danger are inconsistent with the Fourth Amendment and the commands of due process.

$$
* * * *
$$

85. See Amar, supra note 47 , at 1168 n.175.

86. State v. Floyd, 584 A.2d 1157 (Conn. 1991).

87. CONN. GEN. STAT. \& 53a-167b (1991).

88. Floyd, 584 A.2d at 1167. The court listed a number of factors that it thought relevant to determinations of necessity and reasonableness, such as the urgency of the situation, the availability of other officers, and the presence of weapons, but it emphasized that these factors were not exclusive. Id.

89. See California v. Hodari D., 111 S. Ct. 1547, 1551 (1991).

90. See, e.g., California v. Acevedo, 111 S. Ct. 1982, 1989-91 (1991); Coolidge v. N.H., 403 U.S. 443, 520-21 (1971) (White, J., dissenting).

91. Anthony G. Amsterdam, Perspectives on the Fourth Amendment, 58 MNN. L. REv. 349, 394 (1974) (quoting Beck v. Ohio, 379 U.S. 89, 97 (1964)). 
This Essay has not considered the question of whether the townspeople who refused to come to the assistance of the marshal in High Noon or their modern counterparts in the Pratt and Whitney factory visited by Officer Spratto were right or wrong in a moral sense. ${ }^{92}$ That is a question that the dictates of conscience must answer. But constitutional law can and must answer the question of the rights of these citizens. The Framers of our Constitution, in the classic words of the Court in Ex parte Milligan, "were guarding the foundations of civil liberty against the abuses of unlimited power." It is a misuse of power in modern society for an agent of the state to summarily draft a citizen off the street and impress him into hazardous police duty. Our security does not demand that the government be given such power. "If this were true," the Milligan Court observed, "it could be well said that a country, preserved at the sacrifice of all the cardinal principles of liberty, is not worth the cost of preservation. Happily, it is not so." ${ }^{.95}$

92. See supra notes $12-19$ and accompanying text.

93. 71 U.S. (4 Wall.) 2 (1866).

94. Id. at 126.

95. Id. The Court was referring to the proposed suspension of the right to a trial by jury in time of war. 